\title{
KAMUSAL MAKAMLARDA GÖREV SÜRESİ SINIRLAMASI -Tarihsel ve Felsefi Temelleri-*
}

\section{Coşkun Can AKTAN}

Prof.Dr.

Dokuz Eylül Üniversitesi, İktisadi ve İdari Bilimler Fakültesi

E-mail: ccan.aktan@deu.edu.tr

ORCID ID: 0000-0003-4294-2314

\section{Ahmet EKİNC $\dot{I}^{1}$}

Arş.Gör.Dr.

Ankara Hacı Bayram Veli Üniversitesi, Hukuk Fakültesi

E-mail: ahmet.ekinci@hbv.edu.tr

ORCID ID: 0000-0003-0803-6449

\section{$\ddot{O}_{z}$}

Görev süresi sinırlaması bir kamu görevlisinin görevde (makamda) ne kadar süre ile kalabileceği ve ayn görevde (makamda) tekrar bulunup bulunamayacă̆ konularını belirleyen hukuki düzenlemelerdir. Çalışmamızda kamusal makamlarda seçilmişlerin ve atanmışların ne kadar süre (dönem) ile görevde kalmaları gerektiği konusu tarihsel ve felsefi açılardan incelenmektedir. Seçilmişlerin ve aynı zamanda atanmışların görev ve yetkilerinin kapsamının ve genel çerçevesinin önceden belirlenmiş ve sınırlandırılmış olması kadar görev sürelerinin de sinırlandırılmış olması demokrasi idealinin olmazsa olmaz unsurlarıdır. Tarihsel tecrübeleri ve birçok düşünürün eserlerindeki düşüncelerini

* Bu makalede bilimsel araştırma ve yayın etiği ilkelerine uyulmuştur.

${ }^{1}$ Sorumlu Yazar: ahmet.ekinci@hbv.edu.tr

Atıf (APA): Aktan, C. C. \& Ekinci, A., (2021), Kamusal Makamlarda Görev Süresi Sınırlaması Tarihsel ve Felsefi Temelleri-, Hukuk ve İktisat Araştırmaları Dergisi, 13 (1): 83-110.

Lisans: Bu makalenin kullanım izni Creative Commons Attribution-NoCommercial-NoDerivs 3.0 Unported (CC BY-NC-ND3.0) lisansı aracılığıyla bedelsiz sunulmaktadır. 


\section{HUKUK ve İKTISAT ARAŞTIRMALARI DERGİSi}

Cilt: 13 No: 1 Yıl: 2021 ISSN: 2146-0817 (Online)

dikkate alarak modern demokrasilerde görev süresi sinırlaması konusunun anayasalar içerisinde güvence altına alınması gerekir.

Anahtar Kelimeler: Görev Süresi Stnırlaması, Görev Değişimi, Rotasyon, Dönemsel Sinır

Alan Tanımı: Siyaset Bilimi, Kamu Yönetimi, Kamu Tercihi, Anayasa Hukuku

\section{$\begin{array}{lllllll}\text { TENURE IN OFFICE } & \text { AND } & \text { TERM LIMITS IN PUBLIC }\end{array}$ ORGANIZATIONS \\ -Historical and Philosophical Foundations-}

\section{Abstract}

Tenure in office is a statutory regulation that determines how long a public official can stay in office and whether he/she can be elected/appointed in that office for another term. This paper aims to explore conceptual foundations, arguments for and against the term limits. In our study, the issue of how long the elected and appointed officials should stay in office will be examined from historical and philosophical perspectives. It is indispensable for the ideal of democracy that the scope and general framework of the duties and powers of the elected as well as the appointed should be limited. There should be rules and regulations on rotation in office and term limit as well. Considering the historical experiences and thoughts in the works of many philosophers, the issue of rotation in office and term limits in modern democracies should be secured within the constitutions.

Key Words: Term of Office, Tenure of Office, Rotation in Office, Term Limits

JEL Codes: D70, D72, N4, N40

\section{GİRIŞ}

Demokrasilerde görev süresi sınırı ne anlama gelmektedir? İktidarın sınırlandırılması ile görev süresi sınırlaması arasındaki ayrılmaz bağ nedir? İktidarların güç ve yetkilerinin kapsamı ve sınırlarını anayasal kurallara bağlamak neden önemlidir? Demokrasi ve özgürlükler ile görev süresi sınırlaması arasında bir ilişki bulunmakta mıdır? Görev süresi sınırlaması ile alakalı bu ve buna 


\section{HUKUK ve İKTISAT ARAŞTIRMALARI DERGİSi}

Cilt: 13 No: 1 Yıl: 2021 ISSN: 2146-0817 (Online)

benzer sorular esasen anayasacilık ve demokrasi felsefesinin temel meselelerinden birisidir.

Modern demokrasilerin doğuşuna kaynaklık eden Antik Atina demokrasisi başta olmak üzere geçmişten günümüze tüm medeniyetlerde lider ve yöneticilerin, seçilmişler yada atanmışların ne kadar süreyle görevde kalmaları gerektiği konusu daima bir tartışma konusu olmuştur. Bu konuda başta Antik Atina, krallık rejimi sonrasında kurulan Roma Cumhuriyeti ve oldukça detaylı bir seçim ve oylama sistemine sahip olan Venedik Cumhuriyeti görev süresi sınırlaması ya da rotasyon adı verilen uygulamada öne çıkmaktadır. Siyaset felsefesi alanında da bir çok düşünür ve ayrıca anayasacılık felsefesinin öncülüğünü üstlenen devlet adamları anayasanın hazırlanması aşamasında görev süresi sınırlaması konusu üzerine eğilmişlerdir. $\mathrm{Bu}$ çalışmamızın gayesi görev süresi sınırlamasının tarihsel temellerini detaylı olarak ele alarak incelemekten ibarettir.

\section{TARİHSEL TEMELLERI}

Bir kamu görevlisinin görev süresine sınır getirme düşüncesinin kökleri M.Ö. 7. yüzyıl Antik Atina ve M.Ö. 6. yüzyıl Roma Cumhuriyeti dönemlerine kadar gitmektedir. Her iki medeniyete de hâkim olan düşünce "devleti öyle bir kurgulayalım ki en kötü yöneticilerin elinde bile tiranlı̆̆a dönüşmesin!” mantığına dayanır. Yani bu medeniyetlerde devlet, kurumsal olarak en iyi idarecilerin değil en kötü yöneticilerin gelme ihtimaline karşı kurgulanmıştır.

\section{Antik Atina Uygulamast}

Antik Atina demokrasi uygulamasında geçerli olan ilkelere bakıldığında, keyfi yönetimi sınırlayan kuralların ve kurumların varlığı açık biçimde görülmektedir. Antik Atina demokrasisindeki başlıca kurumları on ana başlıkta toplamamız mümkündür (Tablo-1). 


\section{HUKUK ve İKTISAT ARAŞTIRMALARI DERGISİ}

Cilt: 13 No: 1 Yıl: 2021 ISSN: 2146-0817 (Online)

Tablo-1: Antik Yunan'da 10 Temel Demokratik İlke (Kurum)

\begin{tabular}{|c|c|c|}
\hline 1 & Isonomia & $\begin{array}{l}\text { Dēmos'un (halkın) her birinin kanun önünde eşit olmas1 } \\
\text { (Kanun önünde eșitlik ilkesi) }\end{array}$ \\
\hline 2 & Isegoria & $\begin{array}{l}\text { Dēmos'un (halkın) görüș ve düşüncelerini açıçca ifade } \\
\text { edebilmesi (İfade hürriyeti) }\end{array}$ \\
\hline 3 & Sykophantēs & $\begin{array}{l}\text { Dēmos'un (halkın) haksızlık ve hukuksuzluğa karş1 } \\
\text { şikayetlerini bildirme hakkı }\end{array}$ \\
\hline 4 & $\begin{array}{l}\text { Ecclesia, } \\
\text { Bolue,Heliaia }\end{array}$ & $\begin{array}{l}\text { Yasama (Ecclesia), yürütme (Magistrate) ve yarg1 (Heliaia) } \\
\text { organları arasında dengenin gözetilmesi }\end{array}$ \\
\hline 5 & Kleroterion & $\begin{array}{l}\text { Kayırma ve kollamaya izin vermeyen liyakat sistemi } \\
\text { uygulamas1 }\end{array}$ \\
\hline 6 & Sortisyon & $\begin{array}{l}\text { Herkese kamu görevinde bulunabilme imkanı veren } \\
\text { kura ile rastgele seçim sistemi uygulaması }\end{array}$ \\
\hline 7 & Rotasyon & $\begin{array}{l}\text { Aynı görevde uzun süre bulunulmamas1; } \\
\text { mekânsal mobilite uyugulmas1 }\end{array}$ \\
\hline 8 & Ostrakismos & $\begin{array}{l}\text { Güç ve yetki temerküzünden doğan yozlaşmaya karş1 } \\
\text { yöneticilerin sürgüne gönderilmesi uygulamas1 }\end{array}$ \\
\hline 9 & $\begin{array}{l}\text { Liturji } \\
\text { (Leitourgia) }\end{array}$ & $\begin{array}{l}\text { Zengin ve yoksul arasında sosyal adaleti sağlamayı } \\
\text { hedefleyen kamu yararı ve kamu hizmeti anlayış1 }\end{array}$ \\
\hline 10 & Deme & $\begin{array}{l}\text { Gene (genos) adı verilen soyluların güçlerinin } \\
\text { sinırlandırılmasına yönelik bölgesel taksimat uygulaması }\end{array}$ \\
\hline
\end{tabular}

Kaynak: Aktan ve Hallier, 2021'den yararlanılarak hazırlanmıştır.

Aktan ve Hallier Antik Atina demokrasinin temelini oluşturan bu on ilkeyi şu şekilde açıklamaktadır:

"Atinalılar, kanun önünde eşitlik ve adalet ilkesi uygulamass (Isonomia); ifade özgürlüğ̈̈ (Isegoria); yasama (Ecclesia), yürütme (Magistrate) ve yargı (Heliaia, Dikasteria, Nomothetai, Arepagos) organları arasında bir güç dengesi tesis edilmesi ${ }^{2}$; zengin-yoksul ayrımı gözetmeksizin herkesin devlet organlarında görev alabilmesine imkân sağlayan liyakat uygulaması (Kleroterion); kabileler arasında uyum olmasl ve kutuplaşmalara izin verilmemesi için herkese kamu görevlerinde bulunabilme firsatı sunan kura ile rastgele seçim sistemi uygulaması (Sortisyon);

\footnotetext{
${ }^{2}$ Antik Atina tarihi üzerine yazan bazı tarihçiler yasama, yürütme ve yargı güçlerinin bir bütün olarak dēmos'un kontrolünde olduğunu ifade ederler. Biz antik Atina demokrasisinde gerçek anlamda bir "kuvvetler ayrılığı" düşüncesinin olmadığını kabul etmekle beraber Ecclesia, Bolue ve Heliaia/Dikasteria arasında bir denge olduğunu söyleyebiliriz.
} 


\section{HUKUK ve İKTISSAT ARAŞTIRMALARI DERGISİ}

Cilt: 13 No: 1 Yıl: 2021 ISSN: 2146-0817 (Online)

aynı makam ve görevde uzun süre bulunulmaması ve sürekli görev değişimini öngören uygulaması (Rotasyon); güç ve yetkisini kötüye kullanarak iktidarda daha uzun süre kalmaya ĕgilimli olan yöneticilerin kamu makamlarından uzaklaştırılarak sürgüne gönderilmesi uygulaması (Ostrakismos), zengin ya da yoksul haksızlı̆̆a uğrayan tüm vatandaşların istediği zaman kamu görevlilerini şikayet edebilmesi (Sykophantēs) ${ }^{3}$, Atina soylu sınıfinın (Atina aristokrasisinin güç ve yetkilerini sınırlamaya yönelik olarak Atina şehir devlerinin 139 farklı bölgeye (deme) ayrlması uygulamasl, deme (demos) ile gene (genos) arasında yani zengin aristokrat sınıf ile yoksul sinıf arasında sosyal adaleti sağlamayı hedefleyen kamu hizmeti anlayışı (liturji sistemi, leitourgia) gibi gerçekten büyüleyici fikirlere sahiptiler ve bunları da uygulama konusunda bir ölçüde başarılı oldular."

Antik Yunan'da demokratik sistemin temeli özgürlük anlayışına dayanmaktadır. Yani sitedeki her vatandaş özgürlükten pay alır. Bunun amacı vatandaşlar arasında eşitliğin tesis edilebilmesi ve kamu gücünü elinde bulunduranların bu güç vasitasıyla tiranlaşmasının engellenebilmesidir.

Antik Yunan'da bir göreve atanırken kullanılan iki mekanizma, sortisyon (kura sistemi) ve rotasyon (görev değişimi) bir vatandaşın bir makamı ne şekilde işgal edebileceğini daha en baştan belirlenmektedir (Farrar, 2008: 177; Güzel, 2018: 221). Demokrasinin bu pratiğinin Atina şehir devletinde doğrudan tatbik edildiği görülmektedir. Atina'da üst kademe kamu görevlilerinin (magistrate) önemli bir kısmı ve bu kamu görevlilerini denetleyen Halk Mahkemesi üyeleri, özgür vatandaşlar arasından kura yoluyla seçilmekteydi. ${ }^{4} \mathrm{Bu}$ sayede her vatandaşın yönetici olma ve karar alım sürecine doğrudan katılabilmesi sağlanarak vatandaşlar arasındaki eşitsizliğin ve çekişmenin asgariye indirilmesi amaçlanmıştır (Hansen, 1991: 230-231, 235; Farrar, 2008).

\footnotetext{
${ }^{3}$ Hemen belirtelim ki, Solon döneminde başlatılan bu ihbar/şikayet sistemi daha sonra haksız iftira ve suçlamalara yol açarak fazlasıyla yozlaşmıştır. Eski Yunanca "sykophántēs" aslında "bilgi veren" anlamına gelen bir kelime olmasına rağmen yozlaşan uygulama neticesinde "iftira ve karalama yoluyla para kazanan parazit” kişi tanımlamasına dönüşmüştür. Bkz. Lofberg, 1917. Online erişim için bkz. https://archive.org/details/sycophancyinathe00lofb

${ }^{4} \mathrm{Bu}$ görevlilerin çoğu en fazla bir yıl görev yapabilmekte, tekrar aynı göreve seçilememekteydi. Böylece Atina'da her yıl 1100 görevlinin 1000'i yirmi bin vatandaşın bulunduğu bir havuz içerisinden kura yoluyla seçilmiştir. Generallik, finans görevliliği, kutsal görevler, su tedariği ile ilgili işler gibi uzmanlık ve uzun süreli eğitim gerektiren meslekler için ise kura yoluyla değil seçim yoluyla görevlendirme tercih edilmiştir. Hansen, 1991:183.
} 


\section{HUKUK ve İKTISAT ARAŞTIRMALARI DERGISİ}

Cilt: 13 No: 1 Yıl: 2021 ISSN: 2146-0817 (Online)

Ayrıca bu görevler için bir de görev süresi sınırı getirildiği görülmektedir. Zira hem Atina Meclisi'nin ${ }^{5}$ kura ile seçilen ve 500 kişiden oluşan yürütme konseyi (Boule) hem de diğer kamu görevlileri (magistrates) bir yıllık bir süre için seçilmekteydi. $\mathrm{Bu}$ üyeler ömürleri boyunca bu görevde iki yıl boyunca bulunabilmiştir. Boule (Beşyüzler Meclisi), Atina'da bulunan toplamda on kabilenin kura ile belirleyerek gönderdiği 500 üyeden oluşmaktaydı. Boule, 50 kişiden oluşan 10 gruba ayrılmıştı. Her biri yılın onda birinde görev yapmaktaydı. Her gün yeni bir başkan (epistatēs) o anki grubun üyeleri arasından kura yoluyla seçilmekte ve yalnızca günlük olarak görev yapmaktayd $1 .{ }^{6}$ Böylece bir vatandaşın yönetici olduktan kısa bir süre sonra bu görevi terk edeceğini ve yönetilenler arasına katılacağını (Petracca,1996: 1818), aldığı kararlar dolayısıyla da hesap verebileceğini bilmesinin gücünü çıarları yönünde kullanmaktan ve tiranlaşmaktan onu alıkoyacağı düşünülmüştür (Hansen, 1991: 236; Farrar, 2008:179, 183).

Öte yandan görev süresinin kısalığı ve rotasyon sayesinde neredeyse tüm vatandaşların Boule'da görev yapması sağlanmış oluyordu (Dinçkol, 2017:757; Güzel, 2018:219). Bu yöntem vasıtasıyla uzmanlaşma ve kariyer politikacıları yetişmemekte, her makam "ortalama” vatandaşlar eliyle yürütülmektedir. Diğer yandan yürütme üyelerinin vasat/ortalama halinde tutulması, meclisin gücünü korumasını sağlamış iken ${ }^{7}$ rüşvet ve yolsuzluğun, hizipçiliğin azalacağ umulmuştur. ${ }^{8}$ İlaveten Atina'da görevdeki bir siyasinin, görevini kötüye kullandığ

\footnotetext{
${ }^{5}$ Bilindiği üzere Atina şehir devletinde Meclis (Ekklesia) tüm vatandaşların bizzat katılabildiği bir niteliğe sahipti. Bu nedenle oluşumu bakımından bir kura sistemi yoktur. Her vatandaş toplantılara bizzat katılabilmekte idi. Bkz. Dinçkol, 2017: 755.

${ }^{6}$ Vermeule, \& Lanni, 2013:5; Dulani, 2011: 64; Ginsburg et. all. 2011:1818; Dinçkol, 2017: 757; Güzel, 2018: 220. Beekes ve Beek'in anlatımlarına göre Cleisthenes Atina hükümetini M.Ö. 508 'de yeniden düzenlediğinde, dört farklı kabileden oluşan eski Boule'yi kaldırdı ve yerine 500 kişiden oluşan yeni bir boule konseyi oluşturdu. Cleisthenes on yeni kabileyi esas aldı ve boule'yi bu kabilelerin her birinden seçilen 50 temsilciden meydana getirdi. Her kabilenin delegasyonu, yılın onda biri için boule yöneticisi olacaktı, böylece her yıl kura sistemi ile rastgele seçilen bu on grup prytaneis olarak görev yapıyordu. MÖ 5. yüzyılda Atinalı epistatlar (epistatēs) Boule'nin (konseyi) yürütme komitesi görevini icra eden prytaneis'in başkanı olarak görev yaptı. Epistatlar bu ofisin 24 saatlik süresi boyunca hükümetin başı sıfatıyla görev yaptılar, devlet ve hazinenin anahtarlarını muhafaza etmekten sorumlu oldular. Beekes \& Beek, 2010.

${ }^{7}$ Buradaki vasatlık elbette kendi içerisinde etkisiz yürütme gibi bir risk barındırmakta idi ise de Antik Yunan'da bu risk, tiranlık kadar büyük bir risk olarak görülmemiştir. Bkz. Vermeule \& Lanni, 2013:7, 22.

${ }^{8}$ Vermeule \& Lanni, 2013: 6-7; Rotasyon usulünün Dreros on Crete ismindeki küçük bir poliste de tercih edildiği görülmektedir. Bu poliste, devletin baş yöneticilik makamı olan Kosmos
} 


\section{HUKUK ve İKTISAT ARAŞTIRMALARI DERGİSi}

Cilt: 13 No: 1 Yıl: 2021 ISSN: 2146-0817 (Online)

açıçca tespit edilmiş olmasa bile, zengin olması, halk tarafından çok sevilmesi ve belki de bunlar vasıtasıyla daha fazla politik güç elde etmek için uğraşması durumunda da tiranlaşacağından korkulmuştur (Aristoteles, 2015:113). Bunu engellemek için ostrakismos ya da ostrasizm adı verilen bir uygulama kabul edilmiştir. Bu uygulamaya göre halkın oylarının belirli bir sayısı ile (6000 oyla) bu kişinin 10 y1l boyunca siyasi görevlerden men edilmesi ve toplum diş1 bırakılması söz konusudur. Bu tercih bir cezalandırma olarak değil siyasi makamları korumak için bir engelleme mekanizması olarak dikkat çekicidir. ${ }^{9}$

Antik Atina'da uygulanan demokrasi tecrübesini birinci elden ve ilk kaynaktan bugüne aktaran kişilerin başında Aristoteles gelmektedir. Aristoteles Atina Anayasası ve ayrıca Politika adlı eserinde ${ }^{10}$ Antik Yunan şehir devletlerinde uygulama alanı bulan sortiston ve rotasyon konusu üzerinde önemli açıklamalar yapmaktadır. Aristoteles'e göre ise yönetime sırayla geçmek ve sırası geldiğinde yönetilmek bu özgürlüğün bir parçasıdır. Aristoteles, demokrasinin ihtiva ettiği özgürlüğün kullanılabilmesi için şu temel prensiplerin olması gerektiğini ifade etmektedir (Aristoteles, 2015:202-204):

“...seçimlerde tüm vatandaşların seçilme olasılıkları vardır, memuriyete kura ile atanılır -bu durum en azından eğitim gerektirmeyen memuriyetler için geçerlidir- (...) bir kişinin aynı göreve üst üste iki defa seçilememesi bunun istisnaları çok azdır ve genelde savaş durumuna yöneliktir- (...) Bir memuriyette sürekli bulunulmast istenmez. Yine de bir devrimden sonra memuriyet sürekli olarak bir kişide kaldıysa o yetki elinden alınır ve kurayla atama yapılır."

makamında görev yapan bir kişinin görev süresinin 10 yıl olduğu ve tekrar seçilebilmek için 10 yıl beklemesi gerektiği kabul edilmiştir. Eğer ki bir kişi bu süreyi beklemez ve tekrar aynı göreve gelirse, aldığ 1 kararlar ne kadar yerinde olursa olsun bu kişinin ömrü boyunca "kullanışsız", (useless) hale geleceği kabul edilmiştir. Buradaki "kullanışsız" ifadesi bir daha kamu görevine seçilmek gibi bazı medeni haklarını kaybedeceği şeklinde yorumlanmaktadır. Benzer şekilde Sparta'da da Kral'ın gücünü dengelemek için beş kişiden oluşan Ephorate isminde bir heyet oluşturulmuş ve bu heyet üyelerinin görev sürelerinin bir yıl olmasına ve tekrar seçilmenin yasaklanmasına karar verilmiştir. Bkz. Raaflaub \& Wallace, 2007: 65.

9 Buna karşın pratikte söz konusu mekanizmanın, tiranlaşacağından korkulan siyasileri makamından uzaklaştırmak için değil siyasiler tarafından, siyasi rakiplerden kurtulmak amacıyla tercih edilmesi, kurumun amacının tersi yönünde kullanıldığını göstermektedir. Örneğin M.Ö. 480'li y1llarda Themistocles, M.Ö. 461 y1lında ise Pericles siyasi rakiplerinden kurtulmak için bu yönteme başvuran siyasi kişilikler olarak dikkat çekmektedir. Bkz. Vermeule \& Lanni, 2013: 8, 18-19.

${ }^{10}$ Detay bilgi için bkz. Aristoteles, 1989, 2013. 


\section{HUKUK ve İKTISAT ARAŞTIRMALARI DERGİSi}

Cilt: 13 No: 1 Yıl: 2021 ISSN: 2146-0817 (Online)

\section{Roma Cumhuriyeti Uygulamast}

Antik Atina demokrasisindeki görev süresi sınırlaması uygulamasının benzer bir örneğini Roma Cumhuriyeti'nde (M.Ö. 509-M.S. 27) de bulmak mümkündür. Esasen Roma Cumhuriyet rejiminin kurulmasının ana sebebi Roma'nın son kralı Lucius Tarquinius Superbus'un güç ve yetkilerini kötüye kullanarak tiranlığa dönüşen bir rejim ihdas etmiş olmasıdır. Roma Krallığının yedinci ve son Roma Kralı olan Superbus'un (Gururlu Tarquin ya da II. Tarquin olarak da bilinir) tahttan indirilmesi ve krallık rejiminin sona ermesinin $\operatorname{ardından~}^{11}$ ömür boyu iktidarda kalacak olan tek kral yerine halk tarafından bir yıllığına seçilen iki eşit yetkili "consul" (konsül) uygulaması yürürlüğe konulmuştur. Tarihsel kaynaklardaki bilgiler Roma Cumhuriyeti'nde görev süresi sınırlamasına dayalı ikili "konsül” uygulamasının tiranlık rejimine karşı bir önlem olarak düşünüldüğünü anlatmaktadır. Roma Cumhuriyeti'nde sadece konsül değil, diğer seçilmiş ve/veya atanmış görevliler için de görev süresi sınırlaması uygulaması mevcuttu.

Roma Cumhuriyeti'ndeki görev süresi uygulamasını bazı önemli kaynaklar 1şı̆̆ında aktarmaya çalışalım. ${ }^{12}$ Çok genel bir özet vermek gerekirse bu dönemde Cumhuriyet iki farklı consul (konsül) tarafından idare edilmekteydi. Ayrıca Praetor, Quaestor, Tribune, Plebeian Aedile ve Curule Aedile gibi "magistrate" (icra yetkisine sahip üst düzey kamu görevlileri) makamları bulunmaktaydı.

Roma Cumhuriyeti'nde ayrıca vatandaşlardan oluşan ve yasama faaliyetlerini yürüten muhtelif mecisler (Centuriate, Tribal, Plebian) bulunmaktayd1. Bu meclisler magistrate'lerin seçimi ve bazı yargılama faaliyetlerinde de yetkilere sahipti.

Roma Cumhuriyeti'nde başlıca yönetim organları Sanatus ve halk meclislerinden oluşmaktaydı. Konsüller ve magistrate'lar başlıca idari görev organlarıydı. En önemli magistrate görevine sahip makam, sivil ve askerî kumandanlık yetkisine sahip iki konsüldü. Magistrate başlangıçta yalnızca soylulara mahsus bir makamdi; ancak daha sonra plebler olarak bilinen sıradan vatandaşlar da bu göreve kabul edildiler.

11 Kral Superbus M.Ö. 496 yılında Campania'daki Cumae şehrinde sürgünde öldü. Roma vatandaşları mutlak yetkilere sahip bir tirandan kurtulmalarının ardından Cumhuriyet rejimini biçimlendirdiler.

12 Eze, 2016; Posner, 2010; Byrd, 1995; Abbott, 1911; Lintott, 1999. Türkçe literatürde şu iki kaynağa müracaat edilebilir: Umur, 1984; Türkoğlu, 2011. 


\section{HUKUK ve İKTISSAT ARAŞTIRMALARI DERGISİ}

Cilt: 13 No: 1 Yıl: 2021 ISSN: 2146-0817 (Online)

Senatus'un daha ziyade onursal ve danışma (istişari) niteliğinde bir görevi bulunmaktaydı ve yasama yetkisine haiz değildi. Askeri, mali, dini, iç ve diş siyaset konularında Senatus'un tecrübeli üyelerinin görüşlerine ve tavsiyelerine başvurulurdu. Senatus'un üyeleri daha önce farklı Magistrate görevlerinde bulunmuş ve emekli olmuş kişilerden oluşurdu. Senatus üyelerinin doğruluk ve liyakat sahibi saygın insanlardan oluşmasına özen gösterilirdi. Senatus üyeleri yaşamları boyunca o görevde bulunurlardı. Yasama faaliyeti sırasında magistrate'larca getirilen yasa önerileri öncelikle senatus'ta tartışılır ve sonrasında bu öneriler halk meclislerine oylanmak üzere sevk edilirdi. Meclis tarafından kabul edilen yasaların onaylanması ve halka duyurulması senatus tarafindan yerine getirilmekteydi.

Yukarıda da ifade ettiğimiz üzere Roma Cumhuriyeti'nde görev yapan iki Konsül makamı bulunuyordu. Her iki konsül de eşit yetkilere sahipti. Konsüller Senato'ya ve kurullara başkanlık ederler ve hükümet başkanı görevini yürütürlerdi. Konsüllerin ayrica askeri konularda da yetkileri vardı ve orduya başkomutan olarak görev yaparlard1. Konsüller daha önce Praetor makamında bulunmuş olan kişiler arasından seçilirdi ve görev süresi sadece 1 yıldı (Tablo-2).

Tablo-2: Roma Cumhuriyeti'nde “Cursus Honorum” Dâhilindeki Makamlar ve Görev Süresi Sınırlaması

\begin{tabular}{|l|l|l|}
\hline Makam & Görev, Yetki ve Sorumluluk & Görev Süresi \\
\hline Senatus & $\begin{array}{l}\text { Daha önce magistrate makamlarında bulunmuş̧ } \\
\text { saygın kişilerden oluşan Senatus bir tür “Akil } \\
\text { Adamlar Heyeti” olarak görev yapardı. Yasama ve } \\
\text { yürütme faaliyetlerine istişari destek sunard1. }\end{array}$ & Yaşboyu \\
\hline $\begin{array}{l}\text { Konsül } \\
(2)\end{array}$ & $\begin{array}{l}\text { Roma Cumhuriyeti'nde Konsül'lük 2 kişiden } \\
\text { oluşurdu. Daha önce magistrate makamlarında } \\
\text { bulunmuş olanlar arasından seçilir ve görevleri } \\
\text { Senato tarafından onaylanırdı. Senato ve meclislere } \\
\text { toplanıp başkanlı etme, yasa teklifi, yasa } \\
\text { hazırlanması çalışmalarını yürütme, askeri } \\
\text { hareketlerde general olarak görev yapma ve dış } \\
\text { ilişkilerde Roma'yı temsil etme görevlerine } \\
\text { sahiptiler. Görev süreleri tamamlandığında } \\
\text { "proconsul” olarak görev yaparlardı }\end{array}$ & \\
\hline Praetor & $\begin{array}{l}\text { Hukuk mahkemelerinde yargıç olarak görev } \\
\text { yaparlardı; ayrıca Senato ve meclisleri toplayabilme }\end{array}$ & 1 y1l \\
\hline
\end{tabular}




\begin{tabular}{|c|c|c|}
\hline (8) & $\begin{array}{l}\text { yetkileri vardı; Görev süreleri tamamlandığında, bir } \\
\text { idari birimi "propraetor" olarak yönetebilirlerdi. }\end{array}$ & \\
\hline $\begin{array}{l}\text { Quaestor } \\
(20)\end{array}$ & $\begin{array}{l}\text { Yaklaşık } 20 \text { kişiden oluşan bu "magistrate" } \\
\text { görevlileri Roma Cumhuriyeti'nde mali işlerin } \\
\text { yürütülmesinden sorumlulardı. Quaestor olarak } \\
\text { seçilen kişi otomatik olarak Senato'nun da bir üyesi } \\
\text { oluyordu. }\end{array}$ & $1 \mathrm{y} 1 \mathrm{l}$ \\
\hline $\begin{array}{l}\text { Tribunes } \\
\text { (10) }\end{array}$ & $\begin{array}{l}\text { Magistrate'lerin keyfî̀ eylemlerinden korunmak } \\
\text { gayesiyle ihdas edilmiş bir makamdı. Üyelerinin } \\
\text { Plebian olması gerekiyordu. Keyfî ve haksı eylem } \\
\text { yapan Magistrate'lerin eylemini veto etme yetkisine } \\
\text { sahiptiler. Tribune. mecisleri toplama ve yasa } \\
\text { önerisinde bulunma hakkına da sahipti }\end{array}$ & $1 \mathrm{y} 1 \mathrm{l}$ \\
\hline $\begin{array}{l}\text { Aediles } \\
\text { (4) }\end{array}$ & $\begin{array}{l}\text { Roma'da belediye hizmetlerini yürütmek (pazarların } \\
\text { denetlenmesi, tahıl ve su tedariki vs.) ve yurttaşlara } \\
\text { açık oyunlar/festivaller düzenlemekle görevli olan } \\
\text { memurlardı. 2'sinin pleb (sıradan halktan biri) olması } \\
\text { gerekiyordu ve diğer ikisi ise "curule aediles" olarak } \\
\text { adlandırıldı ve daha üst sınıf mensuplarından } \\
\text { seçilirdi. }\end{array}$ & $1 Y_{11}$ \\
\hline $\begin{array}{l}\text { Censor } \\
\text { (2) }\end{array}$ & $\begin{array}{l}\text { Genel olarak nüfus sayımı, vergileme açısından mülk } \\
\text { değerlerinin takdir işlemleri vs. ile görevli olan bir } \\
\text { makamdı. } 18 \text { aylık dönemler için her } 5 \text { yılda bir } \\
\text { seçilirlerdi. }\end{array}$ & 18 ay \\
\hline Dictator & $\begin{array}{l}\text { Savaş ve devletin güvenliğinin tehlikeye girdiği } \\
\text { olağanüstü dönemlerde Konsüllük görevi bir süre } \\
\text { askıya alınır ve yönetme görevi geçici olarak } \\
\text { Dictator adı verilen kişiye geçerdi. Diktatörün görevi } \\
\text { sona erdiğinde tekrar Konsüllerin görevi devam } \\
\text { ederdi. }\end{array}$ & 6 ay \\
\hline
\end{tabular}

Not: Parantez içinde verilen rakamlar o göreve tahsis edilen ve atanacak olan kişi sayısını göstermektedir. 


\section{HUKUK ve İKTİSAT ARAŞTIRMALARI DERGİSi}

Cilt: 13 No: 1 Yıl: 2021 ISSN: 2146-0817 (Online)

İstişari görev yapan Senatus ve hükümeti yönetme görevini üstlenen iki Konsül (Consul) dışında Magistrates adı verilen muhtelif makamlar (Praetor, Quaestor, Tribune, Aedile, Censor, Dicator vs.) bulunmaktaydı. Bunların dışında Censor ve Dictator adı verilen iki ayrı makam daha mevcuttu. Tüm bu sayılan makamlar "Cursus Honorum” adı verilen bürokratik bir sistemi oluşturuyordu. Bürokratik ya da yöneticilik makamına seçilme ve atanma için gerekli olan yeterliliklerin yanısıra görevde kalma süresi de bu sistemin ana parçasıydı. "Cursus Honorum" adı verilen yönetim sisteminde 2 Konsüllük makamı dâhil tüm Magistrate'ler ilke olarak 1 yıl görevde kalma hakkına sahiptiler.

Magistrate makamları ve bu makamda bulunanların görev ve yetkileri ile görevde kalma süreleri Tablo-2'de gösterilmiştir. ${ }^{13}$ Daha önce de not edildiği üzere Senato üyeleri yaşam boyu görev yaparlardı. En yüksek magistrate görevine sahip olan iki konsül ve diğer tüm Magistrate görevlerinde bulunanlar için görev süresi 1 yıldı. Censor unvanı ile görev yapan kamu görevlisinin makamda bulunma süresi $5 \mathrm{y}_{11}^{14}$; Dictator unvanı ile görev yapan kişinin görev süresi ise sadece ve sadece 6 ay ile sinırliyd.

Hemen belirtelim ki, Cursus Honorum dahilindeki her bir makamın/görevin kendine özgü seçilme yaşı vardı. Aynı makamda birden fazla kere görev yapmak yasaklandığı gibi, bir üst makama atanabilmek için de, önceki görevin sona ermesinden itibaren belirli süre ara verilmesi gerekmekteydi. Magistrate'ların görevleri bittikten sonra 10 yıl içerisinde tekrar aynı makama seçilmeleri sözkonusu değildi. Dahası Magistrate makamında görev yapan kişinin 1 yıllık görev süresi sona erdiğinde başka bir Magistrate makamında da 2 yıl boyunca görev yapmasına izin verilmezdi. (Lintott, 1999:113; Türkoğlu, 2011:252).

Buraya kadar yaptığımız özet açıklamalar çerçevesinde bir genel değerlendirme yapmamızın da yararlı olacağını düşünüyoruz. Konsül ve Magistrate'lerin tamamının ülke idaresi için oldukça hayati vazifeler görmelerine karşın ellerinde bulundurdukları bu yetkileri kısa bir süre için tutabiliyor olmaları, üzerlerindeki denetimi artırmış, sınırsız ve keyfî̀ yetki kullanımlarının kolayca geri

\footnotetext{
${ }^{13}$ Hazırladığımız tablonun eksik olduğunu ve mutlaka geliştirilmeye, düzeltilmeye ve eleştiriye açık olduğunu belirtmekte yarar görüyoruz. Zira Roma Cumhuriyeti'nde yönetim konusunda yazılmış eserlerde de bu konuda çok kesin bir bilgi ve bilgiler arasında bir tutarlılık olmadığını söyleyebiliriz. Kaldı ki, sözkonusu görev süresi kuralının zaman içerisinde esnetildiği de ayrıca not edilmelidir.

${ }^{14}$ Tarihsel kaynaklara göre Mamercus Aemilius Mamercinus döneminde Censor'ların görev süreleri onsekiz ay ile sınırlandırılmıştı. Mamercinus Roma Cumhuriyeti'nde M.Ö. 437, 434 ve 426 'da üç kez diktatör olarak görev yaptı.
} 


\section{HUKUK ve İKTİSAT ARAŞTIRMALARI DERGİSi}

Cilt: 13 No: 1 Yıl: 2021 ISSN: 2146-0817 (Online)

alınabilmesini sağlamıştır. Bu dönem için de Antik Yunan polislerinde olduğu gibi kariyer politikacılarından ziyade vasat idarecilerin yönetiminin tercih edilmesinin uzmanlaşmayı engellediği ifade edilmiş ise de yaklaşık 400 yıllık süre boyunca sistemin tiranlaşmayı engelleyerek işler kaldığı da bir gerçektir. ${ }^{15}$

\section{Venedik Cumhuriyeti Uygulamast}

Antik Yunan ve Roma Cumhuriyeti tecrübelerinin Rönesans dönemi Venedik ve Floransa gibi şehir devletlerini de etkilediği bilinmektedir. 7. yüzyıl (697) ile 18. Yüzyıl (1797) arasında İtalya Yarımadası'nda bugünkü Venedik kenti civarında hüküm sürmüş bir kent-devleti olan Venedik Cumhuriyeti'nde uygulanan yönetim (governance) sistemi, seçim ve oylama yöntemleri oldukça karmaşık ve bugünle karşılaştırılmayacak kadar ince ayrıntılara sahip bulunuyordu. Muhtelif kamusal makamlara seçilme yeterlilikleri, seçim ve oylama yöntemlerini vs. dışarıda bırakarak sadece konumuz olan görev süresi sınırlaması konusunu kısaca özetlemeye çalışalım. ${ }^{16}$

Venedik Cumhuriyeti'nde bugün modern demokrasilerde yasama, yürütme ve yarg1 olarak ifade edilen kurumlara denk düşen muhtelif organlar mevcuttu. Maggior Consiglio $^{17}$ (Büyük Konsey), yasama görevini yapan Senato, yürütme organı Collegio ve Kırk'lar Mahkemesi (yüksek mahkeme) ve diğer yarg1 organlarından oluşan bir yönetim sistemi yürürlükteydi.

Venedik Cumhuriyeti'nde devletin en üst yönetimine gelen devlet başkanı ve hükümdar Doçe (İtalyanca, Dòge ) olarak adlandırılırdı. Venedik Cumhuriyeti'nin kurulduğu ilk yıllarda Venedik Doçe'si ülkeyi mutlak otorite altında yönetirdi. Doçe ilk kez 1172 yılında 2000 üyeden oluşan Maggior Consiglio adı verilen

15 Buna karşın Roma Cumhuriyeti toprakları giderek büyümüş, nüfus çeşitlenmiştir. Cumhuriyet'in son yüzyılında sivil idarecilerin görev süresi sınırı nedeniyle popüler olmaması dolayısıyla bilhassa görev süresi üzerinde sınır olmayan ve savaş meydanlarında güç kazanan askeri liderler karşısında etkisizleştikleri ifade edilmektedir. Bu nedenle de konsüllük makamının yalnızca bir yıllık bir süre ile bir kimseye tevcih edilebileceği hükmü ortadan kaldırılarak devletin idaresi, ordunun kuvvet nüfusuna dayanan tek bir kimsenin eline bırakılmıştır. Bkz. Posner, 2010: 7, 17, 24; Akbay, 1951:112.

16 Tablo'nun hazırlanmasında şu kaynaklardan yararlanılmıştır: Doddy, 2007, Ferraro, 2012, Fink,1945, Finlay, 1980, Grendler,1990, 39, Madden, 2012, Norwich, 1989, Petracca, 1996, Pullen, 1971, Smith \& Al-Bawwab, 2017. Not. Roma Cumhuriyeti için verdiğimiz dipnot açıklaması Venedik Cumhuriyeti için de geçerlidir. Burada sunduğumuz tablonun eksik olduğunu ve mutlaka geliştirilmeye, düzeltilmeye ve eleştiriye açık olduğunu belirtmek isteriz. Mevcut kaynakların hiç birinde bu konuda tartışma ve yorumlara mahal bırakmayacak kesin bilgiler mevcut değildir.

${ }^{17}$ Bu Konsey'den önce 12. Yüzyıla kadar Arengo adı verilen bir Halk Meclisi görev yapıyordu. 


\section{HUKUK ve İKTISSAT ARAŞTIRMALARI DERGISİ}

Cilt: 13 No: 1 Yıl: 2021 ISSN: 2146-0817 (Online)

Meclis tarafından seçilen 40 üye tarafından seçilerek göreve getirildi. 1223 yılında ise Signoria adı verilen bir Konsey oluşturularak doçenin gücü iyice azaltıldı. Doçe, Maggio Consiglio tarafından ömür boyu görev yapmak üzere seçilirdi. Maggio Consiglio (Büyük Konsey) üyelerinin görev süresi de daimi idi, yani yaşamları boyunca konsey üyesi olarak görev yaparlardı.

Onlar Konseyi (İtalyanca: Consiglio dei Dieci) 1310-1797 yılları arasında Venedik Cumhuriyeti'nde çalışmalarını gizlilik içerisinde sürdüren bir yönetim organıydı. Adından anlaşılacağı üzere Onlar Konseyi on üyeden oluşmaktaydı ve üyeleri Maggior Consiglio tarafından bir yıllığına seçilmekteydi. Onlar Konseyi üyelerinin arka arkaya iki kez seçilme hakları bulunmuyordu. Ayrıca aynı aileden iki farklı kişi de arka arkaya konsey üyesi olarak görev yapamazdı. Onlar Konseyi üyeleri arasından seçilen bir kişi bir ay boyunca konseyin başkanlık görevini alırdı. Onlar Konseyi 14. Yüzyılın başlarından 18. yüzyılın sonlarına değin görev yaptı ve bu süre içerisinde güç ve yetkileri oldukça genişledi. Onlar Konseyi zamanla yürütme görevlerinin dışında dişişleri, istihbarat, askeriye, yargı süreçlerinde de tek yetkili organ haline geldi.

Tablo-3'e bakıldığında Yüksek Konsey üyeleri, Doçe ve Procurator (maliye ve hazine işlerden sorumlu en yüksek görevli) makamı dışındaki tüm makamlarda bir görev değişimi (rotasyon) ve görev süresi sınırlamasının mevcut olduğu çok açık olarak görülebilir. ${ }^{18}$ Örneğin, 1178 'den sonra, Ducal Councillors (Yöneticiler Konseyi) üyeleri altı ay ya da bir yıl için seçilmeye başlamış ve seçilenlerin görev süresi dolduktan sonraki iki yıl içerisinde tekrar seçilemeyecekleri hükme bağlanmıştır.

Tablo-3: Venedik Cumhuriyeti’nde Görev Süresi Sınırlaması

\begin{tabular}{|l|l|l|}
\hline Makam & Görev, Yetki ve Sorumluluk & Görev Süresi \\
\hline Doçe & $\begin{array}{l}\text { Büyük Konsey (Maggio Consiglio) } \\
\text { tarafindan seçilen Devlet Başkanı }\end{array}$ & Yaşamboyu \\
\hline Büyük & Irsi-ailevi bağları esas alan ve toplam & Yaşamboyu \\
\hline
\end{tabular}

18 Tablo oluşturulmasında birinci derecede Smith \& Al-Bawwab, 2017 esas alınmış, bunun yanısıra şu kaynaklardan da çapraz kontroller yapılmıştır. Doddy, 2007, Ferraro, 2012, Fink,1945, Finlay, 1980, Grendler,1990, 39, Madden, 2012, Norwich, 1989, Pullen, 1971. Tablodaki verilerin doğruluğunun çok daha kapsamlı ve ciddi tarihi kaynaklarla desteklenmeye ihtiyacı olduğu kanaatindeyiz. Buna rağmen açıklamalar Venedik Cumhuriyeti'nde genel anlamda görev süresi uygulamasının benimsendiğini ve yayın olarak uygulandığını ortaya koymaktadır. 


\begin{tabular}{|c|c|c|}
\hline $\begin{array}{l}\text { Konsey } \\
\text { (Maggio } \\
\text { Consiglio ) }\end{array}$ & 400-2500 kişiden oluşan Genel Meclis & \\
\hline Procurator & $\begin{array}{l}\text { Devlet mali işlerinden ve aynı zamanda } \\
\text { mameleklerinin kayıt ve kontrolünden } \\
\text { sorumlu devlet görevlisi. Procurator'lar } \\
\text { ayrıca San Macro Yardım Sandığı'nın } \\
\text { idaresinden sorumluydu. Büyük Konsey } \\
\text { (Maggio Consiglio) tarafından seçilen } 9 \\
\text { kişiden oluşmaktaydı. }\end{array}$ & Yaşamboyu \\
\hline $\begin{array}{l}\text { Senato } \\
\text { (Pregadi) }\end{array}$ & $\begin{array}{l}\text { Doçe, Kırklar Mahkemesi, Büyük } \\
\text { Konsey tarafından seçilen üyeler, daha } \\
\text { önce idari makamlarda bulunmuş } \\
\text { Magistrate vs. olmak üzere yaklaşık } \\
300 \text { üyeden oluşan yasama meclisi. }\end{array}$ & $\begin{array}{l}\text { Magistrate makamı } \\
\text { için görev süresi : } \\
12-16 \text { ay } \\
\text { Büyük Konsey } \\
\text { tarafından seçilen } \\
\text { üyeler: } 1 \text { y1l }\end{array}$ \\
\hline Collegio & $\begin{array}{l}\text { Yürütme Organı (Bakanlar Kurulu = } \\
\text { Kabine) } \\
\text { Savi Grandi (6) Savi Di Terraferma (5) } \\
\text { ve Savi Agli Ordini (5) adı verilen } \\
\text { bakanlardan oluşmaktaydı. Toplam } 16 \\
\text { üyeli Kabine. }\end{array}$ & $\begin{array}{l}\text { Bakanlar için görev } \\
\text { süresi: } 6 \text { ay (tekrar } \\
\text { seçilme/atama } \\
\text { sözkonusu değil) } \\
\text { Collegio Başkanı: 1 } \\
\text { haftalık } \\
\text { başkanlık/rotasyon } \\
\text { geçerli. }\end{array}$ \\
\hline $\begin{array}{l}\text { Ducal } \\
\text { Councilors }\end{array}$ & $\begin{array}{l}\text { Duçe'ye yardımcı olmak üzere görev } \\
\text { yapan bu Konsey Venedik ve } \\
\text { civarındaki } 6 \text { farklı bölgeden } 1 \text { 'er } \\
\text { temsilciden oluşmaktaydı. }\end{array}$ & $\begin{array}{l}1 \text { yil } \\
\text { (tekrar } \\
\text { seçilme/atama } \\
\text { sözkonusu değil) }\end{array}$ \\
\hline $\begin{array}{l}\text { 10'lar } \\
\text { Konseyi }\end{array}$ & $\begin{array}{l}\text { 1310'da ihdas edilen bu yürütme } \\
\text { konseyi. Büyük Konsey tarafından } \\
\text { seçilen } 10 \text { üyeden oluşmaktaydı. }\end{array}$ & $\begin{array}{l}\text { Üyelerin görev } \\
\text { süresi: } 8 \text { ay (tekrar } \\
\text { seçilme/atama }\end{array}$ \\
\hline
\end{tabular}




\begin{tabular}{|c|c|c|}
\hline & & $\begin{array}{l}\text { sözkonusu değil) } \\
\text { Başkanlık makamı: } 2 \\
\text { aylık rotasyon } \\
\text { sistemi }\end{array}$ \\
\hline $\begin{array}{l}\text { 40'lar } \\
\text { Mahkemesi }\end{array}$ & $\begin{array}{l}\text { Quarantia Civile Vecchia'da görev } \\
\text { yapmış yargı üyelerinden oluşan yüksek } \\
\text { mahkeme (anayasa mahkemesi). Büyük } \\
\text { Konsey tarafından seçilen } 40 \text { üyeden } \\
\text { oluşmaktaydı. }\end{array}$ & $\begin{array}{l}\text { Görev süresi: } 1 \text { yıl } \\
\text { (tekrar } \\
\text { seçilme/atama } \\
\text { sözkonusu değil) } \\
\text { Başkanlık makamı: 1 } \\
\text { aylık rotasyon }\end{array}$ \\
\hline $\begin{array}{l}\text { Devlet } \\
\text { Savc1lar1 }\end{array}$ & $\begin{array}{l}\text { Büyük Konsey tarafından seçilen } \\
\text { üyelerden oluşmaktaydı. }\end{array}$ & $\begin{array}{l}\text { Üyelerin görev } \\
\text { süresi: } 16 \text { ay }\end{array}$ \\
\hline Signoria & $\begin{array}{l}\text { Duçe'nin karar ve eylemlerini izleyen, } \\
\text { gözetleyen ve veto yetkisi olan kurum. } \\
\text { Duçe }+40 \text { 'lar Mahkemesi Üyeleri }+ \\
\text { Ducal Councilors üyelerinde } \\
\text { oluşmaktaydı. }\end{array}$ & (b.y) \\
\hline
\end{tabular}

Not: (b.y) = bilgi yok

\section{AYDINLANMA ÇAĞI'NDA GÖREV SÜRESININ SINIRLANDIRILMASI ÜZERINE DÜŞÜNCELER}

Kamusal makamlarda görev süresinin sınırlandırılması doğrudan "sınırlı devlet" ve "anayasacılık" felsefesi üzerine eserler kaleme almış olan birçok filozofun da ilgilendiği bir konu olmuştur. Keyfî̀ devlet yerine anayasal hukuk devleti anlayışının öncüleri olarak kabul edeceğimiz tüm düşünürler devletin güç ve yetkilerinin hem kapsam hem de süre olarak sınırlandırılmasının önemi üzerinde durmuşlardır.

Görev süresi sınırlamasını savunan fikirler Antik Yunan'a kadar uzanmış olsa da modern demokrasilerde sınırlı devlet-sınırlı iktidar düşüncesinin oluşmasında John Locke ve John Trenchard gibi düşünürler öncü bir rol üstlenmişlerdir. 


\section{HUKUK ve İKTISAT ARAŞTIRMALARI DERGİSi}

Cilt: 13 No: 1 Yıl: 2021 ISSN: 2146-0817 (Online)

Özgürlük felsefesinin en güçlü savunucularından biri olarak kabul edilen İngiliz düşünür John Locke'un (1632-1704) izinde özgürlük yazıları (Cato Mektupları) ${ }^{19}$ kaleme alan John Trenchard (1662-1723) "Anayasal Devlet" adını taşıyan 61 numaralı Cato mektubunda şunları yazmıştır:

"Güç ve Yönetimde Rotasyon özgür Devlet için gereklidir: nasıl ki Can Insan bedeninin parçası ise rotasyonda devlet yönetimi için o kadar önemlidir. Özgürlüğün kutsal kabul edildiği her yerde rotasyon da kutsal ve dokunulmaz bir ilkedir;"

“Halkın Özgürlüğünü korumak için sık sık yapılan yeni Seçimleri çok önemli görüyorum: Bu, Politika yazarlarının Yönetimde Rotasyon (Rotation of Magistracy) olarak adlandırdiğg şeydir. Insanlar Yönetime (Magistracy) ilk girdiklerinde, genellikle eski Durumlarını Gözlerinin Önünde getiriler: Gücün Kötüye Kullanılmasından, Dostlarl ile birlikte neleri çektiklerini ve ne kadar suçladıklarını hatırlarlar; ve böylece onların ilk Amaçları alçakgönüllü, mütevazı ve adil olmaktır; ve muhtemelen, bir süre böyle devam ederler. Ancak Iktidara Sahip Olma, sahte Dostların aldatıcı Tütsüsü ve Parazitlerin secdeye varması Kalplerini çok geçmeden değiştirir. Önce, tüm iyi Tasarımlarına kayıtsız kalırlar, sonra onları bırakırlar: Sonra, Ilımlı pozisyonlarını kaybederler; daha sonra eski Tanıdık ve eski İlkeleri ile tüm Önlemlerden vazgeçerler; ve kendilerini, Büyüleyici Gözlüklerde, Büyüklük ve Küstahlık içinde, Arkadaşlarından farklı bir Türde görmeye başlarlar ve böylece küstah, açgözlü ve tiran haline gelirler, hayali Büyüklükleri kadar servetlerini de büyütmek için çoğu zaman en aşağıllk ve en baskıcı yollara girmeye hazır olurlar."

Kamu görevlilerinin görev süresine sınır konulması düşüncesi benzer şekilde İngiliz iç savaşına tanık olan James Harrington (1611-1677) tarafından da dile getirilmiştir. Düşünür, bir cumhuriyetin esenliği için kamu görevlerinde rotasyonun temel olduğunu ifade etmiştir (Petracca, 1996: 250). Yazar için, sürekli parlamentoya geri dönen bir vekil, normalde taze oksijen ile zenginleşmesi gereken bir akciğere sürekli dönen kan hücresine benzemektedir (Erickson, 1995: 400-2). Harrington rotasyonun olmadığı bir sistemde seçimlerin

19 Cato Mektupları John Trenchard (1662-1723) ve arkadaşı Thomas Gordon (1692-1750) tarafından kaleme alınmış 138 metinden oluşmaktadır. Cato Mektupları 1720-1723 arasında kaleme alınmıştır. 


\section{HUKUK ve İKTISAT ARAŞTIRMALARI DERGİSi}

Cilt: 13 No: 1 Yıl: 2021 ISSN: 2146-0817 (Online)

anlamsızlaşacağını, rotasyon sayesinde ise yöneticilerin halkınkinden bağımsız, kendi menfaatlerinin peşinde gideceğini ifade etmiştir (Petracca, 1996:251).

İngiliz özgürlük mücadelesi yıllarında Kral I. Charles'ın idamının üzerinden 7 y1 ve kralların güç ve yetkilerinin mutlak ve sınırsız olduğu düşüncesinin felsefi temellerini yazan İngiliz düşünür Thomas Hobbes'in Leviathan (1651) adlı eserinin üzerinden 5 y1l geçtikten sonra Oceana (1656) adlı eseri yazan James Harrington Aristotles'in izinde ideal bir anayasa tasarımı yapmaya çalışmış ve sınırlı devlet düşüncesini savunmuştur.

Harrington sözkonusu eserinde görev süresinin sınırlandırılması konusunu rotasyon adı altında çok ayrıntılı bir şekilde inceler. ${ }^{20}$ Söz konusu eserinde "iyi düzenlenmiş bir devlet için rotasyon gerekli mi? ${ }^{21}$ sorusuna "Tersine, rotasyon çarkını çöpe atarak yönetimde görev süresinin uzatılması bir devletin doğal işleyişini yok eden bir uygulamadır",2 cevabını verir. Ayrıca yazar "Denge ve kontrole karşı olan hükümet, tiranlıktır" ${ }^{23}$ ve "keyfî güç kullanan bir krala sahip olmak ve herhangi bir kontrole tabi olmayan keyfî bir güç, tamamen tiranlık anlamına gelir" ${ }^{24}$ görüşlerini savunur.

İngiliz İç Savaş yıllarında Tesviyeciler (Leveller) adı verilen halk hareketinin de görev süresinin sınırlandırılması konusundaki görüş ve mücadelelerini hatırlamamızda yarar vardır. Tesviyeciler John Lilburne, Richard Overton ve William Walwyn öncülüğünde bir grup insan tarafindan başlatılmıştır. Anayasacılık hareketleri için çok önemli bir yeri olan Tesviyeciler tarafından hazırlanan bir anayasa metninde de görev süresi sınırlamasını çok açık olarak görebilmekteyiz.

Tesviyeciler, mücadeleleri sonunda 1649 y1lında Ingiltere Halkının Anlaşması (An Agreement of the Free People of England) adını taşıan önemli bir manifesto

\footnotetext{
${ }^{20}$ James Harrington, 1771. The Oceana and Other Works of James Harrington, with an Account of His Life by John Toland (London: Becket and Cadell, 1771) ayrica bkz. The Oceana and Other Works of James Harrington, with an Account of His Life by John Toland (London: Becket and Cadell, 1771).https://oll.libertyfund.org/title/toland-the-oceana-and-otherworks\#Harrington_0050-version3_1248

21 "Whether courses or a rotation be necessary to a well-order'd commonwealth?

22 "The contrary wherto is prolongation of magistracy, which, trashing the wheel of rotation, destroys the life or natural motion of a commonwealth."

23 "Government against the balance in one, is tyranny."

24 "but to have bin a king exercising arbitrary power, and such arbitrary power as, being without any bounds, fully amounts to tyranny."
} 


\section{HUKUK ve İKTISSAT ARAŞTIRMALARI DERGISİ}

Cilt: 13 No: 1 Yıl: 2021 ISSN: 2146-0817 (Online)

yayınladılar. Tesviyecilerin başlattı̆ğ mücadele bir anayasacılık hareketidir ve nihai bildirge (1649) esasen bir anayasa metnidir.

Tesviyeciler anayasasının dördüncü maddesinde mevcut parlamento üyelerinin hiçbir üyesinin bir sonraki parlamentoya üye seçilemeyeceğini, yalnızca muhtelif kamu görevlerinde çalışabileceklerini vurgulamaktadır. Bildirgenin bir sonraki maddesinde ise bu kez aynı kişinin uzun süre iktidarda bulunmasının çeşitli rahatsızlık ve hatta tehlikelere yol açacağına değinilmekte, buna da tıpk1 parlamento üyelerinde olduğu gibi bir sınırlama getirilmesinin önemli olduğuna dikkat çekilmektedir. Böylece parlamentonun bütün üyeleri görev yaptıkları 1 yılın sonunda hiçbir güç ve yetkiye sahip olamayacaklardır. Bildirgenin altıncı maddesinde mevcut parlamentonun bir sonraki seçimleri düzenleme, yeni parlamenterlerin seçimi vb. konularda sorumluluğuna vurgu yapılmaktadır (Aktan \& Yay, 2019).

"Mevcut parlamentonun hiçbir üyesi bir sonraki temsilcilik için seçilme niteliğine sahip değildir ve gelecekteki herhangi bir temsilciliğin herhangi bir üyesi kendisinden hemen sonra gelen meclise seçilme ehliyetine sahip değildir."

Parlamentoya seçilmiş olan bir milletvekilinin bir sonraki dönem tekrar seçilebilme imkânını ortadan kaldıran mantık, söz konusu anayasa metninde şu sözlerle ifade edilmiştir: (Aktan \& Yay, 2019).

V.-Aynı kişinin iktidarda uzun süre bulunmasından ortaya çıkan çeşitli rahatsızlık ve tehlikelerden kaçınmak için (...)

İngiliz İç Savaşı sonrasında bir çok düşünür de "rotasyon" olarak adlandırdıkları görev süresinin sınırlandırılmasının önemi üzerine yazılar kaleme almışlardır. Örneğin, İngiliz siyasetçi ve düşünür James Burgh (1714-1775) Politik İncelemeler veya Kamusal Hatalar, Kusurlar ve Görevi Kötüye Kullanımlara Yönelik Araştırma (Political Disquisitions; or an Enquiry into Public Errors, Defects, and Abuses' (1774-1775) başlığını taşıyan eserinde parlamento üyelerinin görev süresinin sınırlı olması konusunu çok ayrıntılı olarak incelemiştir.

Burgh'in yazıları 1789 Amerikan Anayasası'nın yazımında da doğrudan etkili olmuştur. (Hay, 1979).

İngiltere'nin en önde gelen radikal reform savunucularından biri olarak kabul edilen James Burgh eserinin Rotasyon Yoluyla Tekrar Seçilememe (Of Exclusion by Rotation ) adını taşıyan 6.bölümde şunları yazmaktadır: 


\section{HUKUK ve İKTISSAT ARAŞTIRMALARI DERGISİ}

Cilt: 13 No: 1 Yıl: 2021 ISSN: 2146-0817 (Online)

"parlamentoya seçilme süresinin rotasyon uygulaması olmaksızın azaltılması radikal bir tedaviyi değil, yalnızca bir rahatlamayı să̆lar. ,25

“Çünkü parlamentolar yıllık olsaydı ve milletvekillerinin üç yıl boyunca üçte ikisi hariç tutulsaydı tüm kötü uygulamalar (rüşvet verilmesi vs.) sona ererdi; çünkü parlamento, iki yıl boyunca hiçbir zaman tamamen aynı adamlardan oluşmamış olacaktı." (Burgh,1775:130)

“...yöneticilerin güç ve yetkileri sılklkla değiştirilmedikçe, özgürlük asla korunamayacaktır. Özgürlük ve bağımsızlı, dünyanın tüm ülkelerinde yönetimde sıklıkla yapılan değişiklikler yani rotasyon uygulamasıyla korunmuştur" (Burgh,1775:165).

İngiltere'de iç savaç öncesi ve sonrasında diplomat ve siyasetçi Henry Neville (1564-1615), siyaset adamı ve siyaset felsefesi düşünürü Algernon Sidney (16231683), John Trenchard'ın yakın arkadaşı İngiliz siyasi yazar ve politikacı Walter Moyle (1672-1721), İngiliz hukukçu ve siyaset adamı William Blackstone (17231761), İngiliz roman yazarı ve felsefi anarşizmin öncülerinden biri kabul edilen William Godwin (1756-1836) gibi isimleri de görev süresi sinırlamasını savunanlar arasında yer almışlardır.

Aydınlanma çağının hemen başlarında bu görüşler daha sonra diğer anayasacılık hareketlerine de yansımıştır. Görev süresinin sınırlandırılması düşüncesi ABD’yi kuran temel iradede kendisini göstermektedir. ABD'yi kuran pek çok eyaletin anayasasında görev süresi sınırı çeşitli kamu görevleri için daha en başından itibaren kendisine yer bulmuştur (Petracca, 1996:254). 1776-1789 y1lları arasında Konfederasyon yapısı altında da kimsenin Konfederasyon Kongresi üyeliğine altı yıllık bir dönemde üç yıldan daha fazla bir süre için seçilemeyeceği düzenlenmekteydi. ${ }^{26}$ Devamında, parlamenterlerin görev süresine sınır konulması fikri Federal Anayasanın hazırlanması döneminde yoğun bir şekilde tartışılmış fakat kabul görmemiştir. ${ }^{27}$

25 "The shortening of parliaments alone, without exclusion by rotation, would prove only a palliation, not a radical cure”. Burgh, 1775:174.

${ }^{26}$ Hatta bu hüküm kapsamında Samuel Osgood'un üyeliği düşürülmüştür. Bkz. Altman, 2008. Rausch, 1991: 400.

${ }^{27}$ Federal Anayasa içerisinde görev süresi sınırı fikrinin en önemli savunucuları arasında James Madison yer almaktadır. Madison, daha en başından itibaren tekrar seçilmeye izin verilmesinin Kongre üyelerinin seçmenlerin değil kendi dar menfaatlerinin peşinden gitmelerine imkân tanıyacağına inanmış ve bunu savunmuştur. Fakat bu görüşü gereken sayıda destek bulmamıştır. Madison'u destekleyenlerden biri olan Thomas Jefferson hoşuma gitmeyen, gerçekten 


\section{HUKUK ve İKTISAT ARAŞTIRMALARI DERGİSi}

Cilt: 13 No: 1 Yıl: 2021 ISSN: 2146-0817 (Online)

Demokrasi fikri, Antik Yunan ve Roma Cumhuriyeti tecrübelerinden derinden etkilenen ABD kurucularının ruhuna işlediğini söylemek yanlış olmayacaktır. Böylece rotasyon fikri yazılı olmasa da uygulama vasitasıyla hayata geçirilebilmiştir. İlk devlet başkanı George Washington (1732-1799) iki dönem devlet başkanlığı yaptıktan sonra tekrar aday olmamıştır. Washington'un bu yöndeki tercihinin ardında, daha fazla siyasi makam peşinde olmanın Cumhuriyet'in temelinde yer alan kamusal erdem fikri ile bağdaşmayacak olmasının bulunduğu ifade edilmektedir. ${ }^{28}$ Washington "seçilmiş görevlilerinin rotasyonu [halkın arzu ettiği] özgürlük ve güvenlik sağlayacak bir uygulamadır",29 görüşünü savunarak üçüncü dönem görev yapma hakkından gönüllü olarak vazgeçmiştir.

2. ABD Başkanı olarak görev yapan John Adams (1735-1826) da görev süresi sınırlaması (rotasyon) uygulamasını benimseyen bir kurucu liderdi. Adams'ın şu bilgelik dolu sözlerini aktarmaya değerdir: ${ }^{30}$

"Seçimler, özellikle temsilciler ve yargı kurumlarının üyeleri için yıllık olmalı; tüm bilim dünyasında bundan daha şaşmaz bir özdeyiş yoktur: 'ylllı seçimlerin bittiği yerde kölelik başlar.' Bu önemli görevlere talip olan) büyük adamlar ... yllda bir kez seçilmelidir.

"Maddeler denizdeki kabarcıklar gibi yükselirler, kırllırlar ve denize geri dönerler. "31

Bu onlara alçakgönüllülüğün, sabrın ve ölçülülüğün büyük siyasi erdemlerini ögrretir; iktidardaki her insan açgözlü bir canavara dönüşür."

memnuniyetsiz olduğum bir şey görevde rotasyon gerekliliğinin her durumda terk edilmiş olmasıdır." diyecektir. Bkz. Erickson, 1995: 400-401.

${ }^{28}$ Washington'un bu kararı almasına etki eden unsurun Roma'lı Cincinnatus'dan esinlenmesi olduğu ifade edilmektedir. Cincinnatus Romalı bir çiftçidir. Ulusun savunulması gerektiğinde sabanını bırakıp silaha sarılmış ve askeri başarıları ile ün kazanmıştır. Buna karşın savaş bittikten sonra Cincinnatus bu kez de silahı bırakıp, elde edebilecek olmasına rağmen siyasi makam peşinde koşmaksızın tekrar çiftliğine dönmüştür. Cincinnatus'u bu yönde eylemde bulunmaya iten motivasyonun para ya da şöhret değil de kamusal erdem olması, Cumhuriyeti en iyi izah eden örnek olarak yüceltilmektedir. Bkz. Erickson, 1995: 403.

${ }^{29}$ George Washington, Letter to Madison, May 20, 1792. Works, vol. xii, p. 383. Şu kaynaktan aluntı yapılmıştır: Whitridge, 1889. Orijinal sözleri şu şekildedir: "The spirit of government may render a rotation in the elected officers of it most congenial with the ideas of liberty and safety."

${ }^{30}$ Thoughts on Government John Adams | 1776

https://teachingamericanhistory.org/library/document/thoughts-on-government/

31 "Like bubbles on the sea of matter borne, They rise, they break, and to that sea return." John Adams burada İngiliz hiciv şairi Alexander Pope (1688-1744)'un bu sözüne atıfta bulunmaktadır: 


\section{HUKUK ve İKTISAT ARAŞTIRMALARI DERGİSi}

Cilt: 13 No: 1 Yıl: 2021 ISSN: 2146-0817 (Online)

Temsilciler ve yargı üyelerinin yanı sıra tüm görev ve makamlarda rotasyonu savunan ve bunu bir çok makul argümanla tartışan insanlar bulunmaktadır. Toplum böyle bir rotasyonla yapılacak çok sayıda boşluğu karşılamaya yetecek saylda uygun karaktere sahip yönetici potansiyeline sahipse buna bir itiraz göremiyorum. Bu kişilerin üç yll hizmet etmesine izin verilebilir ve daha sonra görev dışında bırakılabilir."

Öte yandan 1809-1817 arasında Amerika Birleşik Devletleri'nin 4.başkanı olarak görev yapan James Madison (1751-1836) da rotasyon ilkesini benimseyen bir düşünür ve devlet adamı idi. James Madison Fransa'da Louis XVI Mahkemesi Büyükelçisi olarak hizmet veren Thomas Jefferson'a yazdığı bir mektubunda rotasyon konusunda yapılan tartışmalardan duyduğu memnuniyetini dile getirdi; bununla birlikte, daha fazla kontrol ve dengenin olması gerektiğine şu sözlerle vurgu yaptı:

"Sevmediğim ve büyük ölçüde hoşlanmadı̆̆ım ikinci husus görevde rotasyon uygulamasının özellikle de Başkanlık makamı açısından terk edilmiş olmasıdır. Tecrübe gösterir ki, en yüksek makamda olan Başkan Anayasa izin verirse tekrar seçilmek isteyecektir. Bu durumda ömür boyu Başkan olacak demektir. ",32

1829-1837 yılları arasında ABD’nin 7. Başkanı olarak görev yapan Andrew Jackson da başkanlık makamında bulunma süresinin sınırlı olması gerektiğini savundu. 8 Aralı 1829 tarihinde görevi devraldıktan sonra yaptığı ilk konuşmadaki şu sözleri aktarmaya değerdir: ${ }^{33}$

"Görev değişimi yanlış bir uygulama değildir. Ortaya çıkabilecek tek yanlış, (tekrar seçilmesine izin verilmeyen) iyi adamların yerine kötülerinin gelmesidir."

Hemen not edelim; Amerikan tarihinde "Spoils" sistemi adı verilen partizan kayırma-kollama sisteminin (patronaj sistemi) öncüsü olarak kabul edilen ve sıklıkla eleştirilen Andrew Jackson'un rotasyonu savunan bu görüşlerinin daha etraflı bir şekilde değerlendirilmesi gerekebilir.

\footnotetext{
${ }^{32}$ Letter to James Madison, Thomas Jefferson | December 20, 1787 https://teachingamericanhistory.org/library/document/letter-to-james-madison-19/

${ }^{33}$ Bkz.Andrew Jackson, "First Annual Address," December 8, 1829, in James D. Richardson, ed., II A Compilation of the Messages and Papers of the Presidents, 1789-1908. (Bureau of National Literature and Art, 1909). Online erişim için bkz.

https://onlinebooks.library.upenn.edu/webbin/metabook?id=mppresidents
} 


\section{HUKUK ve İKTISAT ARAŞTIRMALARI DERGİSi}

Cilt: 13 No: 1 Yıl: 2021 ISSN: 2146-0817 (Online)

ABD'nin kurucu önderlerinden Alexander Hamilton ise George Washington, James Madison, John Adams'dan farklı olarak başkanlık görevinin süre ile sınırlandırılması düşüncesine karşı çıkmıştır. Hamilton'a göre tekrar seçilemeyeceğini bilen bir politikacı görevin gerektirdiği azmi göstermeyecek, özellikle hayati konular bakımından sorumluluk almaktan kaçınacaktır (Hamilton, 2008: 355-357; Petracca, 1996:264). Alexander Hamilton (1755-1804) kurucu önderlerden biri olmasının yanısıra Amerika Birleşik Devletleri'nin ilk partisi olan Federalist Parti'nin de kurucusudur. Aynı zamanda ilk Hazine Bakanı olarak görev yapan Hamilton Amerika Birleşik Devletleri'nin mali sisteminin kurucusu olarak kabul edilir. Hamilton "Yürütme Organının Görevde Kalma Süresi" (The Duration in Office of the Executive) başlığını taşıyan 71 No'lu Federalist Papers içinde şunları yazmaktadır.

“... beyler gayretlerini makul sinırların ötesine taşlyarak rotasyonu savunuyorlar. Bu zaylf ilkeye dayanan hiçbir hükümetin iyi işleyemeyeceğine inanıyorum. Diğer devletlerin sahip olduğu rotasyon uygulamasindan kaynaklanan sorunları dikkate almıyoruz; ve onların rotasyona itirazlarının gerekçelerini pek bilmiyoruz. Eyaletlerin çoğunu bu değişikliği kabul etmeye ikna etme olasılığımız yok. Beyler kendilerini kandirıyor. Bir adam görevinden ayrılması gerektiğini bildiğinde, bırakın erdemi ne olursa olsun; dikkatini esas olarak kendi menfaatine çevirecektir: ... iktidarını anayasaya aykırı gasplarla sürdürme peşinde olacaktır. "34

Hamilton'a göre görev süresi sınırlaması uygulaması etkisiz idare ortaya çıkarır. $\mathrm{Bu}$ iddiaya göre uzmanlaşmış ve tecrübe kazanmış politikacıların tam da bu birikimlerinden yararlanılacağı zamanda görevlerinden alınmaları söz konusudur.

Hamilton gibi Amerika Birleşik Devletleri'nin kurucu önderlerinden birisi olan ve ayrica Thomas Jefferson, Benjamin Franklin, John Adams ve Roger Sherman ile birlikte Bağımsızlık Bildirgesi'ni hazırlayan Beşler Komitesi'nin bir üyesi olarak görev yapan Robert Robert Livingston (1746-1813) da Federal Anayasanın kabulüne ilişkin olarak New York tartışmaları sırasında görev sınırlaması önerisine şu sözlerle karşı çıkmıştır:

"Kendilerini temsil edecek kişileri seçme konusunda en doğruyu bilecek olan insanların kendileridir. Onlara kimi seçmeyeceklerini söylemek, dikte etmek ve kontrol etmek onların doğal haklarını çiğnemek anlamına gelir.

\footnotetext{
${ }^{34}$ Bkz. New York Ratifying Convention. First Speech of June 25, [25 June 1788] Founders Online , https://founders.archives.gov/documents/Hamilton/01-05-02-0012-0027.
} 


\section{HUKUK ve İKTISSAT ARAŞTIRMALARI DERGISİ}

Cilt: 13 No: 1 Yıl: 2021 ISSN: 2146-0817 (Online)

Rotasyon saçma bir ostracism türüdür; üstün liyakat sahibi olan insanlart sürgüne gönderme yoludur. Ayrıca, kamusal erdemin en güçlü dürtüsünü şeref ve ödül- ortadan kaldırır. (...) Hepimiz tecrübenin iyi bir yönetim için gerekli olduğunu biliyoruz. Öyleyse tecrübeyi karanlı̆̆a sürükleyelim mi? Bunun, halkın haklarını elinden almak olduğunu tekrarlıyorum.

Nihai olarak görev süresi sınırlaması 1951 yılında yapılan 22. anayasa değişikliği ile bir anayasa kuralı haline gelmiştir (Bkz. Kennedy, 2019). 18. ve 19. yüzyıl boyunca parlamenterlerin de gönüllü emeklilik kararı alarak tekrar aday olmamayı tercih etmeleri ile bu kültürün devam ettirildiği ifade edilmektedir (Erickson, 1995:403). Rotasyonun hem başkanlık hem de parlamenterlik makamında devamlılık kazanması ile, ilgili yüzyıllarda, ABD politikasının siyasal fikir ve uygulama planında, yazılı olan karşısında daha eşitlikçi hale geldiği ifade edilmektedir (Erickson, 1995:404).

Diğer yandan, anayasal olarak, ilk görev süresi sınırı uygulamaları 19. yüzyılda Latin Amerika' da karşımıza çıkmaktadır. Bağımsızlık hareketlerini takiben, görev süresine sınır getirilmeyen başkanların tiranlaşacağı yönündeki uyarılarının kıtada kabul edilen anayasalara sirayet ettiği görülmektedir (Baturo, 2010: 637; Carey, 2003:121). 1990'lardan itibaren ise demokratikleşme yönünde ivme kazanan bazı Afrika devletleri, yeni geçiş yaptıkları demokratik yönetim modelini muhafaza etmek maksadıyla devlet başkanlarının görev sürelerine sınırlar getiren anayasa hükümlerini kabul etmişlerdir ve bu eğilim önünde bazı engeller olsa da devam etmektedir. $^{36}$ Özetle günümüzde kamu görevlilerinin, özellikle devlet

\footnotetext{
${ }^{35}$ Bu alıntıyı şu kaynaktan yapmış bulunuyoruz: The debates in the several state conventions on the adoption of the federal Constitution, as recommended by the general convention at Philadelphia, in 1787. Together with the Journal of the federal convention, Luther Martin's letter, Yates's minutes, Congressional opinions, Virginia and Kentucky resolutions of '98-'99, and other illustrations of the Constitution ... $2 \mathrm{~d}$ ed., with considerable additions. Collected and rev. from contemporary publications, by Jonathan Elliot. Pub. under the sanction of Congress. (1836), 5 vols.

https://oll.libertyfund.org/title/elliot-the-debates-in-the-several-state-conventions-5-vols https://oll.libertyfund.org/title/elliot-the-debates-in-the-several-state-conventions-vol-2

${ }^{36} 1990$ yılından önce Afrika'da yalnızca 6 ülkenin anayasasında görev süresi sınırı söz konusu olmasına karşın 1990-1999 yılları arasında kabul edilen 66 anayasanın \%89'unda görev süresi sınırı yer alır. Hatta bazı ülkelerin bu maddeleri değişmez maddeler olarak düzenledikleri görülmektedir. Mangala. 2020: 6; Albert, 2010: 687-688; Dulani, 2015:1.
} 
başkanlarının, görev sürelerine sınır getirme düşüncesinin modern dönemlerde giderek yaygınlık kazandı̆̆ 1 kabul edilmektedir. ${ }^{37}$

\section{SONUÇ}

İnsanoğlunun medeniyet yolculuğunda demokrasi yönündeki mücadeleler neticesinde bugüne değin kazanımlarımız hiç de küçümsenmeyecek derecede önemlidir. Dünyada özellikle 20. Yüzyıldan itibaren demokratikleşmenin hız kazanması, daha sonra bu ivmenin yavaşlaması ve tersine demokratikleşme dalgasına dönüşmesi yönündeki eğilimleri pekâlâ biliyoruz. İçinde yaşadığımız 21. Yüzyılda dünyanın birbirinden farklı coğrafyalarında demokratik standartlarda açık bir gerileme, demokratik kurumların ele geçirilmesi, demokrasinin vazgeçilmez ilkelerinin ve kurallarının erozyona uğraması vs. uygulamalar fazlasıyla yaygınlık kazanmıştır. Seçime dayalı demokrasilerde depotizm, tiranlık, otoriterleşme ya da otokrasi olarak adlandırılan bu vahim gelişmelerin önlenmesi ancak ve ancak mütemadi siyasi liderliğin anayasanın zincirlerine bağlanması ile mümkündür. Bir devlet ya da hükümet başkanı gücünü milletten aldığını ifade ederek ve millet iradesi adı verilen bir retorik ya da hurafeye sığınarak mütemadi siyasi liderliğe meşruluk kazandıramaz. Hiç bir siyasi parti başkanı partizan delegelerden oluşan bir olağan parti genel kongresinde oyların tamamını ya da mevsuf çoğunluğunu aldığını iddia ederek zaferini ilan edemez.

Seçilmişlerin ve aynı zamanda atanmışların görev ve yetkilerinin kapsamının ve genel çerçevesinin önceden belirlenmiş ve sınırlandırılmış olması kadar görev sürelerinin de sınırlandırılmış olması demokrasi idealinin olmazsa olmaz unsurlarıdır. Demokrasi fikriyatının ilk ortaya çıktığı Antik Atina başta olmak üzere Antik Roma ve Venedik Cumhuriyetlerinde modern demokrasilere örnek olacak harikulade koruyucu anayasal sinırlamalar mevcuttu. Aydınlanma çağındaki fikirler ise anayasacılık felsefesinin altın yılları olarak tarihe geçmiştir. 21. Yüzyılda dünyanın dört bir yanında birçok ülkede anayasacılık felsefesinin unutulmuş ve otokrasiye doğru eğilimlerin hızlanmış olması doğrusu oldukça vahim ve üzüntü verici gelişmelerdir. Modern demokrasilerde uzun süreli keyfi ve kalıcı iktidarları ve mütemadi siyasi liderliği sınırlayacak anayasal kural ve kurumların oluşturulmasının elzem olduğunu düşünüyoruz.

37 1789-2006 arasında düzenlenen 960 anayasanın 480’i (\%60) devlet başkanların görev süreleri üzerinde sınır öngörmektedir. Bkz. Ginsburg, Melton, Elkins, 2011:1835. 


\section{HUKUK ve İKTISAT ARAŞTIRMALARI DERGİSi}

Cilt: 13 No: 1 Yıl: 2021 ISSN: 2146-0817 (Online)

\section{KAYNAKÇA}

Abbott, F. F. (1911). A History And Description Of Roman Political İnstitutions, (3rd ed.). Boston: Ginn \& Co.

Aktan, C.C. ve Hallier, M.F. (2021). Devlet İdaresinde Temsilcilerin ve Yöneticilerin Seçilmesi Ve/Veya Atanmasında Kura Sistemi (Rastgele Seçim): Antik Atina Tecrübesi, Sosyal ve Beşeri Bilimler Dergisi, 13:1.

Aktan, C.C. \& Yay, S. (2019). Tesviyeciler Manifestosu: Bir Sivil Anayasa Önerisi Anayasal Demokrasi ve Anayasal Hukuk Devletine Yönelik Eşsiz Bir Yazılı Anayasa Metni . Sosyal ve Beşeri Bilimler Dergisi , 11 (2) , 100-128.

Albert, R. (2010). "Constitutional Handcuffs". Arizona State Law Journal, Vol. 42, pp. 663-715.

Altman, D. (2008). “A Brief History of Term Limits”. Time. http://content.time.com/time/nation/article/0,8599,1846988,00.html, (Erişim tarihi: 8.3.2021.)

Aristoteles. (1989). The Athenian Constitution. (Translated by. H. Rackham), Loeb Classical Library. Cambridge, Harvard University Press.

Aristoteles, (2013). Atinalıların Devleti, (Çev: A. Çokona). İstanbul, T. İş Bankası Yayınları, Hasan Ali Yücel Klasikleri.

Aristoteles, (2015). Politika. (Çev. Furkan Akderin). İstanbul: Say Yayınları, 2. Bask1.

Baturo, A. (2010) "The Stakes of Losing Office, Term Limits and Democracy", British Journal of Political Sciences, Vol: 40, No: 3, p. 637.

Beekes, R. S. P., \& Beek, L. (2010). Etymological Dictionary of Greek. Leiden: Brill.

Burgh, J. (1775). Political disquisitions; or, An enquiry into public errors, defects, and abuses. Illustrated by, and established upon facts and remarks, extracted from a variety of authors, ancient and modern. : Calculated to draw the timely attention of government and people, to a due consideration of the necessity, and the means, of reforming those errors, defects, and abuses; of restoring the constitution, and saving the state. / By J. Burgh, gentleman; author of the Dignity of human nature, and other works. ; Volume the first [-third and last]. Philadelphia:: Printed and sold by Robert Bell, in Third-Street; and William Woodhouse, in Front-Street., M,DCC,LXXV. http://name.umdl.umich.edu/N10941.0001.001 


\section{HUKUK ve İKTISSAT ARAŞTIRMALARI DERGISİ}

Cilt: 13 No: 1 Yıl: 2021 ISSN: 2146-0817 (Online)

Byrd, R. (1995). The Senate of the Roman Republic. U.S. Government Printing Office Senate Document 103-23.

Carey, J. (2003) "The Reelection Debate in Latin America". Latin American Politics and Society, Vol: 45, No: 1.

Erickson, S. C. (1995). "The Entrenchening of Incumbency: Reelections in the U.S. House of Representatives, 1790-1994". Cato Journal. Vol. 14. No. 3. pp. 397-419.

Eze, K. (2016). “The Efficacy of Presidential Term Limits".Mandela Institute for Development Studies. Tanzania.

Dinçkol, B. (2017). “Atina Demokrasisinden Roma Cumhuriyetine-“Demos”tan "Populus Romanus"a". Marmara Üniversitesi Hukuk Fakültesi Hukuk Araştırmaları Dergisi Prof. Dr. Bülent Tahiroğlu'na Armağan. 23:3.

Dulani, B. (2015). "African Publics Strongly Support Term Limits, Resist Leaders' Efforts to Extend Their Tenure". Afro-Barometer No. 30. https://afrobarometer.org/publications/ad30-african-publics-strongly-supportterm-limits-resist-leaders-efforts-extend-their, (Erişim tarihi: 6.3.2021.)

Elliot, J. (1836). Pub. under the Sanction of Congress. (1836), 5 vols. https://oll.libertyfund.org/title/elliot-the-debates-in-the-several-state-conventions5-vols https://oll.libertyfund.org/title/elliot-the-debates-in-the-several-stateconventions-vol-2 (Erişim tarihi: 8.3.2021.)

Farrar, C. (2008). "Power to the People", Origins of Democracy in Ancient Greece. Ed. Kurt a. Raaflaub, Josiah Ober, Robert Wallace, University of California Press, Berkeley, Los Angeles, London, pp. 170-197.

Ferraro, J. M. (2012). Venice: History of the Floating City. New York, NY: Cambridge University Press.

Finlay, R. (1980). Politics in Renaissance Venice. New Brunswick, NJ: Rutgers University Press.

Grendler, P. F. (1990). "The Leaders of the Venetian State, 1540-1609: A Prosopographical Analysis," Studi Veneziani 19: 35-85.

Ginsburg, T.; Melton, J.; Zachary, E. (2011). "On the Evasion of Executive Term Limits". William and Mary Law Review. 52(6). pp. 1807-1872.

Güzel, M. N. (2018). “Antik Demokrasi ve Modern Demokrasi Kavramlarının Kuvvetler Ayrılığı İlkesi Çerçevesinde Değerlendirilmesi”. DÜHFD. C. 23, Sa. 38, ss. 205-231. 


\section{HUKUK ve İKTISSAT ARAŞTIRMALARI DERGISİ}

Cilt: 13 No: 1 Yıl: 2021 ISSN: 2146-0817 (Online)

Hamilton, A. (2008). Federalist Papers No: 72, Ed. Lawrence Goldman, Oxford World's Classics, Oxford University Press.

Hansen, M. H. (1991). Athenian Democracy in the Age of Demosthenes, (Translated by. J. Crook). Blackwwell Publishers, Cambridge.

Harrington, J. (1771). The Oceana and Other Works of James Harrington, with an Account of His Life by John Toland (London: Becket and Cadell, 1771) ayrica bkz. The Oceana and Other Works of James Harrington, with an Account of His Life by John Toland (London: Becket and Cadell, 1771).https://oll.libertyfund.org/title/toland-the-oceana-and-otherworks\#Harrington_0050-version3_1248 (Erişim tarihi: 6.3.2021.)

Hay, C. (1979). The Making of a Radical: The Case of James Burgh. Journal of British Studies, 18(2), 90-117.

Kennedy, L. (2019). How FDR Became the First-And Only-President to Serve Four Terms, History, https://www.history.com/news/fdr-four-term-president-22amendment, (Erişim tarihi: 26.3.2021.)

Lintott, A.W. (1999). The Constitution of the Roman Republic. Oxford University Press.

Lofberg, J.O. Sycophancy in Athens, (1917). Collegiate Press, Banta Publishing Company. Online erişim için bkz.

https://archive.org/details/sycophancyinathe00lofb

https://books.google.com.tr/books/about/Sycophancy_in_Athens.html?id=Rh4sA

QAAMAAJ\&redir_esc $=\mathrm{y}$

Madden, T. F. (2012). Venice: A New History. New York, NY: Viking.

New York Ratifying Convention. First Speech of June 25, [25 June 1788] Founders Online erişim: https://founders.archives.gov/documents/Hamilton/0105-02-0012-0027.

Norwich, J. J. (1989). A History of Venice. New York, NY : Vintage Books.

Petracca, M. P. (1996). “A History of Rotation in Office”. Legislative Term Limits: Public Choice Perspectives. Ed. Bernard Grofman. Kluwer Academic Publishers. Boston/Dordrecht/London.

Posner, E. A. (2010). "The Constitution of the Roman Republic: A Political Economy Perspective”. John M. Olin Law \& Economics Working Paper No. 540. Public Law and Legal Theory Working Paper No. 327. 


\section{HUKUK ve İKTISAT ARAŞTIRMALARI DERGİSi}

Cilt: 13 No: 1 Yıl: 2021 ISSN: 2146-0817 (Online)

https://chicagounbound.uchicago.edu/cgi/viewcontent.cgi? article=1496\&context= law_and_economics, (Erişim tarihi: 4.3.2021.)

Pullen, B. (1971). Rich and Poor in Renaissance Venice: The Social Institutions of a Catholic State to 1670. Blackwell Publishers.

Rausch, J. D. (1991). "When a Popular Idea Meets Congress: The History of the Term Limit Debate in Congress". Politics Bureacracy \& Justice Journal 1, no. 1, pp. 34-43.

Smith, D. J. and Al-Bawwab, R. (2017). Constraining Elites: The Self-Enforcing Constitution of the Patricians of Venice (February 15, 2017). Available at SSRN: https://ssrn.com/abstract=2851157

Türkoğlu, G.H. (2011). Roma Cumhuriyet ve İlk İmparatorluk Dönemlerinin İdari Yapıs1", Dokuz Eylül Üniversitesi, Hukuk Fakültesi Dergisi Cilt: 11, Sayı 2, 251289.

Umur, Z. (1984). Roma Hukuku- Tarihi Giriş, Kaynaklar- Umumi MefhumlarHakların Himayesi, İstanbul.

Vermeule, A, \& Lanni, A. (2013). "Precautionary Constitutionalism in Ancient Athens", https://ssrn.com/abstracy=2115570, (Erişim tarihi: 4.3.2021)

Wallace, R. W. (2007). “'People's Power' and Egalitarian Trends in Archaic Greece". Origins of Democracy in Ancient Greece. Ed. Kurt a. Raaflaub, Josiah Ober, Robert Wallace, University of California Press, Berkeley, Los Angeles, London, pp. 22-48.

Whitridge, F.W. (1889). "Rotation in Office", Political Science Quarterly, Vol. 4, No. 2 (Jun., 1889), pp. 279-295. 